\title{
Efek Paparan Kronis Pestisida Terhadap Kadar Aspartat Aminotransferase (AST) Dan Alanin Aminotransferase (ALT) Pada Subyek Petani
}

\author{
Devyana Dyah Wulandari ${ }^{1}$, Andreas Putro Ragil Santoso ${ }^{1}$, Devyani Diah Wulansari ${ }^{2 *}$ \\ ${ }^{1}$ Prodi D-IV Analis Kesehatan, Fakultas Kesehatan \\ Universitas Nahdlatul Ulama Surabaya \\ ${ }^{2}$ Fakultas Farmasi \\ Universitas Surabaya \\ Correspondence to: devyanidiahwulansari@staff.ubaya.ac.id
}

\begin{abstract}
Tanggal Submit: 25 Agustus 2020

Tanggal Review:

5 November 2020

Tanggal Publish

Online:

10 Desember 2020

Farmers in Indonesia are very dependent on pesticides to protect their crops from pests. Farmers are one of the subjects who are susceptible to pesticides and can cause disease due to pesticide accumulation. One of the disease that can arise due to exposure to pesticides is liver damage. This study wanted to determine the effect of pesticide exposure on liver damage seen from AST and ALT enzyme levels using farmer respondents in the Mojokerto area of 25 respondents. From the results of the study it was found that AST levels were influenced by age $(\mathrm{P}=$ 0.017), length of work $(P=0.035)$, and PPE usage $(P=0.044)$, while age, work period, length of work and usage of PPE did not significantly influence to ALT levels. It can be concluded that age, length of work and use of PPE affect AST levels. Therefore, to prevent the occurrence of pesticide poisoning, farmers must obey the rules on the use of pesticides such as using PPE regularly and always consuming healthy food.
\end{abstract}

\section{PENDAHULUAN}

Pestisida merupakan zat kimia dan bahan lain termasuk jasad renik dan virus yang dipergunakan untuk memberantas atau mencegah hama-hama dan penyakit yang merusak tanaman, bagian-bagian tanaman atau hasil-hasil pertanian (Permentan, 2015), namun di sisi lain pestisida sangat dibutuhkan oleh petani untuk melindungi tanamannya (Yuantari, 2015). Berdasarkan dari data Kementerian Pertanian mengemukakan bahwa petani di Indonesia menjadi sangat tergantung dengan keberadaan pestisida, terbukti telah terjadi peningkatan jumlah pestisida dari tahun ke tahun dengan jumlah paling banyak yang digunakan adalah insektisida (Direktorat Jendral Prasarana dan Sarana Direktorat Pupuk dan Pestisida Kementerian Pertanian, 2011). Resiko Kesehatan yang dihadapi oleh pekerja perusahaan pestisida, petani maupun masyarakat semakin meningkat seiring dengan tingginya penggunaan pestisida. 
Cara pemakaian pestisida sangat berkaitan dengan resiko yang dialami oleh pengguna pestisida. sedangkan risiko kesehatan yang diderita oleh masyarakat luas umumnya karena terjadinya pencemaran pestisida yang masuk pada rantai makanan, dan keracunan pestisida, baik akibat tertelan atau terhirup pestisida maupun akibat kontak langsung melalui kulit. Setiap hari ribuan petani dan para pekerja di pertanian diracuni oleh pestisida dan setiap tahun diperkirakan jutaan orang yang terlibat di pertanian menderita keracunan akibat penggunaan pestisida. Berdasarkan data dari organisasi kesehatan dunia (WHO) dan program Lingkungan Persatuan Bangsa-bangsa (UNEP), 1 - 5 juta kasus keracunan terjadi pada pekerja yang bekerja di sektor pertanian. Selain itu masyarakat sekitar lokasi pertanian sangat berisiko terpapar pestisida baik melalui udara, tanah dan air yang ikut tercemar, bahkan konsumen melalui produk pertanian yang menggunakan pestisida (Wulandari, 2020).

Hati merupakan salah satu organ target pestisida. Akumulasi pajanan pestisida yang masuk ke dalam hati tidak dapat diuraikan serta dieksresikan dan tersimpan dalam hati akan menyebabkan gangguan sel atau organel hati. Hal ini mengakibatkan kerusakan pada parenkim hati atau gangguan permeabilitas membran sel hati sehingga enzim bebas keluar sel. Sebagai respon terhadap kerusakan pada hati maka konsentrasi enzim dalam darah akan meningkat (Tsani RA, 2017). Peningkatan Enzim transaminase serum aspartate amino transferase (AST) atau serum glutamate oxaloacetate transaminase (SGOT) dan Alanine amino transferase (ALT), atau serum glutamat piruvat transaminase (SGPT) merupakan indicator telah terjadi kerusakan hati. Kadar serum AST dan ALT meningkat ketika terjadi kerusakan jaringan yang memproduksinya (Mishra, 2012).

Petani merupakan subyek yang rentan terpapar pestisida. Berdasarkan hasil analisis situasi, banyak keluhan yang timbul dari para petani daerah Mojokerto yang mengindikasi adanya gejala keracunan. Sedangkan solusi sementara yang telah dilakukan adalah dengan istirahat untuk sementara waktu dan belum ada cara untuk meminimalisir gejala keracunan yang timbul.

Berdasarkan uraian yang telah dipaparkan di atas, maka perlu dilakukan penelitian untuk mengetahui pengaruh paparan pestisida terhadap gangguan 
fungsi hati pada petani di wilayah

\section{METODE PENELITIAN}

\section{Alat dan Bahan}

Alat dan bahan yang diperlukan pada penelitian ini antara lain spuit $3 \mathrm{cc}$ merk Terumo, torniquet, masker, hand scoon, vacutainer plain, mikropipet, kapas alkohol, Sentrifus Merk TOMY Tipe MX-105, Photometer. Sedangkan bahan yang digunakan dalam penelitian ini antara lain sampel darah responden, aquadesreagen AST dan reagen ALT.

\section{Prosedur Kerja}

1. Pengambilan sampel darah

Proses pembendungan dilakukan menggunakan tourniquet kemudian mengoleskan kapas beralkohol secara memutar sebagai antiseptik dan dibiarkan kering. Jarum spuit ditusukkan pada posisi $30-45^{\circ} \mathrm{C}$ sampai muncul tanda darah keluar dari jarum kemudian spuit ditarik sampai batas 2 yang menunjukkan volume darah sebanyak $2 \mathrm{~mL}$. Jarum diambil dari vena dan darah dimasukan kedalam tabung vacum tainer yang berisi EDTA kemudian dihomogenkan. (EFLM (European Federation of Clinical Chemistry and Laboratory Medicine) Recommendation for Venous Blood Sampling, 2017).
Mojokerto.

2. Pemisahan eritrosit dan plasma

Darah yang telah dimasukkan dalam vacum tainer disentrifus menggunakan Sentrifus Merk TOMY Tipe MX105 selama 10 menit dengan kecepatan 4000 rpm. Eritrosit yang sudah terpisah dengan plasma diambil dan diletakkan dalam tabung reaksi (Standard Operating Procedure for Collecting, Proccessing, and Storage of Blood Samples, 2017).

3. Pengukuran kadar AST dan ALT

Prosedur pemeriksaan AST: Sampel serum diambil sebanyak $20 \mu \mathrm{l}$ dimasukkan ke dalam tabung reaksi, kemudian ditambah dengan $1000 \mu \mathrm{l}$ reagen AST, dicampur dan diinkubasi pada suhu $37^{\circ} \mathrm{C}$ selama I menit. Baca absorben pada fotometer dengan Panjang Gelombang 340, Faktor 1745, Program K 20. Prosedur pemeriksaan ALT: sampel serum diambil sebanyak $20 \mu \mathrm{l}$ dimasukkan ke dalam tabung reaksi kemudian ditambah reagen ALT sebanyak $1000 \mu$ l. Campur dan inkubasikan pada suhu $37^{\circ} \mathrm{C}$ selama 1 menit. Baca absorben setelah tepat 1 menit, 2 menit, dan 3 menit pada Panjang Gelombang 340, Faktor 1745 dan pada Program K 20. 


\section{HASIL PENELITIAN}

Penelitian ini dilakukan didaerah Mojokerto dengan respondennya adalah petani yang setiap harinya terpapar pestisida. Semua petani didaerah Mojokerto berjenis kelamin laki-laki berjumlah 25 orang dengan usia, lama kerja, masa kerja dan pemakaian alat pelindung diri (APD) yang berbeda-beda seperti yang terlihat pada tabel 1 . Responden dengan usia >50 tahun sebanyak 16 orang (64\%) berjumlah lebih banyak daripada usia $<50$ tahun dengan jumlah 9 orang (36\%) dengan usia paling muda adalah 32 tahun dan usia paling tua adalah 64 tahun. Masa kerja responden dibagi menjadi 4 kategori, dengan jumlah paling banyak adalah masa kerja 5-10 tahun (32\%) dan $>15$ tahun (32\%). Berdasarkan lama bekerja, responden dibagi menjadi 3 kategori dengan jumlah paling banyak dengan lama kerja 3-6 jam/hari sebanyak 12 orang $(48 \%)$. Sedangkan berdasarkan pemakaian APD dapat dilihat bahwa jumlah yang tidak memakai APD $(60 \%)$ lebih banyak daripada yang menggunakan APD (40\%). Responden rentan mengalami keracunan pestisida karena mereka setiap hari bekerja dan terpapar oleh pestisida, bahkan terdapat responden yang tidak memakai APD saat bekerja. .

Tabel 1. Distribusi jumlah responden berdasarkan variable bebas

\begin{tabular}{|l|l|l|l|}
\hline Variabel & Kategori & $\mathbf{N}$ & $\mathbf{\%}$ \\
\hline \multirow{4}{*}{ Usia } & $<50$ th & 9 & 36 \\
\cline { 2 - 4 } & $>50$ th & 16 & 64 \\
\hline \multirow{4}{*}{ Masa Kerja } & $1-5$ th & 5 & 20 \\
\cline { 2 - 4 } & $5-10$ th & 8 & 32 \\
\cline { 2 - 4 } & $10-15$ th & 4 & 16 \\
\cline { 2 - 4 } & $>15$ th & 8 & 32 \\
\hline \multirow{4}{*}{ Lama Kerja } & $1-3$ jam/hari & 9 & 36 \\
\cline { 2 - 4 } & $3-6$ jam/hari & 12 & 48 \\
\cline { 2 - 4 } & $6-9$ jam/hari & 4 & 16 \\
\hline \multirow{2}{*}{$\begin{array}{l}\text { Pemakaian } \\
\text { APD }\end{array}$} & Ya & 10 & 40 \\
\cline { 2 - 4 } & Tidak & 15 & 60 \\
\hline
\end{tabular}

Parameter gangguan fungsi hati yang diperiksa antara lain AST dan ALT. Hasil pemeriksaan kadar AST dan ALT dapat dilihat pada tabel 2. Hasil menunjukkan bahwa kadar AST dan ALT petani di daerah Mojokerto masih termasuk ke dalam kategori normal. Kadar normal untuk AST dengan range antara 24.00-38.00 U/l, sedangkan kadar normal untuk ALT dengan range antara 22.00-35.00 U/l. Adanya gangguan fungsi hati dapat diketahui dengan melihat apakah terdapat peningkatan kadar AST dan ALT yang merupakan indikator telah terjadi kerusakan hati 
Tabel 2. Hasil Pemeriksaan Kadar AST dan Kadar ALT

\begin{tabular}{|c|c|c|c|c|}
\hline $\begin{array}{l}\text { Kode } \\
\text { Pasien }\end{array}$ & $\begin{array}{l}\text { Kadar } \\
\text { AST }\end{array}$ & $\begin{array}{l}\text { Range } \\
\text { Kontrol } \\
\text { AST } \\
\text { (U/L) }\end{array}$ & $\begin{array}{l}\text { Kadar } \\
\text { ALT }\end{array}$ & $\begin{array}{l}\text { Range } \\
\text { Kontrol } \\
\text { ALT } \\
\text { (U/L) }\end{array}$ \\
\hline $\mathbf{A}$ & 27,48 & \multirow{25}{*}{$\begin{array}{l}24,00 \\
38,00\end{array}$} & 23,15 & \multirow{25}{*}{$\begin{array}{l}22,00 \\
35,00\end{array}$} \\
\hline B & 26,25 & & 29,31 & \\
\hline C & 26,64 & & 24,76 & \\
\hline D & 26,77 & & 28,01 & \\
\hline $\mathbf{E}$ & 26,49 & & 26,86 & \\
\hline $\mathbf{F}$ & 23,82 & & 27,16 & \\
\hline G & 25,38 & & 30,22 & \\
\hline $\mathbf{H}$ & 27,63 & & 30,2 & \\
\hline I & 26,24 & & 28,36 & \\
\hline $\mathbf{J}$ & 23,73 & & 26,28 & \\
\hline K & 28,24 & & 27,78 & \\
\hline $\mathbf{L}$ & 25,41 & & 27,83 & \\
\hline M & 29,40 & & 30,59 & \\
\hline $\mathbf{N}$ & 23,81 & & 27,34 & \\
\hline O & 24,60 & & 28,32 & \\
\hline $\mathbf{P}$ & 25,05 & & 25,3 & \\
\hline $\mathbf{Q}$ & 24,00 & & 29,27 & \\
\hline $\mathbf{R}$ & 26,65 & & 27,57 & \\
\hline $\mathbf{S}$ & 27,27 & & 27,68 & \\
\hline $\mathbf{T}$ & 24,42 & & 29,17 & \\
\hline $\mathbf{U}$ & 25,61 & & 23,86 & \\
\hline V & 24,01 & & 26,64 & \\
\hline W & 24,53 & & 23,46 & \\
\hline $\mathbf{X}$ & 25,46 & & 30,93 & \\
\hline $\mathbf{Y}$ & 25,14 & & 29,54 & \\
\hline
\end{tabular}

Hasil analisis statistik dari 4 variabel bebas (usia, masa kerja, lama kerja dan pemakaian APD) terhadap kadar AST dan ALT dapat dilihat pada tabel 3. Hasil menunjukkan bahwa faktor usia memiliki pengaruh terhadap kadar AST dengan nilai $\mathrm{P}=0,017$ dan tidak memiliki pengaruh terhadap kadar ALT dengan nilai $\mathrm{P}=0,449$. Untuk masa kerja responden tidak memiliki pengaruh terhadap kadar AST $(\mathrm{P}=0,992)$ maupun ALT $(P=0,716)$. Berdasarkan variabel lama kerja memiliki pengaruh terhadap kadar AST $(\mathrm{P}=0,035)$ namun tidak memiliki pengaruh terhadap kadar ALT $(\mathrm{P}=0,980)$. Berdasarkan variabel pemakaian APD diketahui bahwa pemakaian APD memiliki pengaruh terhadap kadar AST $(\mathrm{P}=0,044)$ namun tidak memiliki pengaruh terhadap kadar $\operatorname{ALT}(\mathrm{P}=0,853)$.

Tabel 3. Hasil analisis statistik variable bebas terhadap kadar AST dan ALT

\begin{tabular}{|c|c|c|c|}
\hline $\begin{array}{l}\text { Variabel } \\
\text { Bebas }\end{array}$ & $\begin{array}{l}\text { Variabel } \\
\text { Terikat }\end{array}$ & $\mathrm{P}$ & $\begin{array}{l}\text { Keterangan } \\
\text { (pada } \mathrm{P}=0,05 \text { ) }\end{array}$ \\
\hline \multirow[b]{2}{*}{ Usia } & AST & 0,017 & Ada pengaruh \\
\hline & ALT & 0,449 & $\begin{array}{ll}\text { Tidak ada } \\
\text { pengaruh }\end{array}$ \\
\hline \multirow{2}{*}{$\begin{array}{l}\text { Masa } \\
\text { Kerja }\end{array}$} & AST & 0,992 & $\begin{array}{ll}\text { Tidak } & \text { ada } \\
\text { pengaruh } & \end{array}$ \\
\hline & ALT & 0,716 & $\begin{array}{ll}\text { Tidak ada } \\
\text { pengaruh }\end{array}$ \\
\hline \multirow{2}{*}{$\begin{array}{l}\text { Lama } \\
\text { Kerja }\end{array}$} & AST & 0,035 & Ada pengaruh \\
\hline & ALT & 0,980 & $\begin{array}{ll}\text { Tidak } & \text { ada } \\
\text { pengaruh } & \end{array}$ \\
\hline \multirow{2}{*}{$\begin{array}{l}\text { Pemakaian } \\
\text { APD }\end{array}$} & AST & 0,044 & Ada pengaruh \\
\hline & ALT & 0,853 & $\begin{array}{ll}\text { Tidak } & \text { ada } \\
\text { pengaruh } & \end{array}$ \\
\hline
\end{tabular}

\section{PEMBAHASAN}

Pengaruh Usia terhadap Kadar AST dan ALT

Hasil analisis statistik menggunakan One Way ANOVA menunjukkan bahwa faktor usia berpengaruh signifikan terhadap kadar AST $(\mathrm{P}=0,017)$ pada petani di wilayah Mojokerto. Hal ini tidak sejalan dengan penelitian Rehman pada tahun 2017 yang menyebutkan bahwa faktor usia tidak memiliki pengaruh yang signifikan terhadap kadar AST pada pekerja pabrik 
pestisida di wilayah Pakistan. Sedangkan pada hasil analisis statistik menunjukkan bahwa faktor usia tidak memiliki pengaruh yang signifikan terhadap kadar ALT $(\mathrm{p}=0,449)$ pada petani di wilayah Mojokerto. Hal ini sejalan dengan penelitian yang dilakukan oleh Rizvi pada tahun 2013 yang menunjukkan bahwa tidak ada hubungan yang signifikan antara faktor usia dengan peningkatan kadar ALT pada pasien rumah sakit di Islamabad. Namun menurut Fowler (2003) dalam Lomanorek (2016) menyebutkan bahwa usia $>45$ tahun masuk dalam fase klinik. Pada fase ini terjadi penurunan aktivitas hormon seperti dehydroepiandrosterone (DHEA), growth hormone (GH), melatonin, estrogen, testosterone, dan hormon tiroid. Pada fase ini juga terjadi penurunan kemampuan dalam menyerap nutrisi, vitamin, dan mineral sehingga tubuh akan lebih mudah terpapar oleh radikal bebas yang bersifat sangat reaktif. Pada kondisi ini, radikal bebas akan lebih mudah merusak molekul yang ada didalam tubuh seperti DNA, lemak, protein sehingga menyebabkan terjadinya kerusakan sel yang selanjutnya dapat memicu munculnya beberapa penyakit. Radikal bebas tersebut dapat ditimbulkan oleh beberapa hal diantaranya polusi, asap rokok, dan paparan bahan kimia seperti pestisida. Paparan radikal bebas dapat menimbulkan terjadinya peroksidasi lipid yang merusak membran sel pada organ hati dan jantung sehingga terjadi peningkatan kadar enzim transaminase yang merupakan indikator telah terjadi kerusakan hati.

\section{Pengaruh Masa Kerja terhadap Kadar}

\section{AST dan ALT}

Berdasarkan hasil analisis statistik One Way ANOVA menunjukkan bahwa masa kerja tidak memiliki pengaruh yang signifikan terhadap kadar AST $(\mathrm{P}=0,992)$ dan ALT $(\mathrm{P}=0,716)$ pada petani di wilayah Mojokerto. Hal ini tidak sesuai dengan hasil penelitian Tsani pada tahun 2017 yang menunjukkan bahwa terdapat pengaruh masa kerja terhadap kadar AST dan ALT pada petani di Desa Sumberejo Kecamatan Ngablak Kabupaten Magelang. Menurut Tsani, pengaruh masa kerja terhadap gangguan fungsi hati disebabkan karena semakin lama petani terpapar pestisida maka akan menyebabkan pestisida terakumulasi dalam tubuh. Keberadaan pestisida yang terlalu banyak didalam tubuh akan menyebabkan mengganggu kinerja beberapa organ dalam tubuh, salah satunya adalah hati. Pestisida dapat 
merusak membran sel dalam hati sehingga menyebabkan enzim yang berada di sitosol akan masuk ke peredaran darah diakibatkan adanya perbedaan permeabilitas membran sel sehingga kadar enzim aminotransferase dalam darah meningkat. Namun, menurut Widarti pada tahun 2019 menyatakan bahwa kadar AST dan ALT yang normal pada petani dapat disebabkan oleh proses metabolisme xenobiotic (termasuk pestisida) yang masih baik. Proses metabolisme xenobiotic terjadi didalam hati dengan mengubah xenobiotic menjadi bentuk lain yang aman dan tidak memberikan efek negatif bagi tubuh. Selain itu, pemakaian alat pelindung diri (APD) pada petani juga akan mengurangi paparan pestisida sehingga kadar AST dan ALT masih dalam range normal.

\section{Pengaruh Lama Kerja terhadap Kadar AST dan ALT}

Hasil analisis statistik One Way ANOVA menunjukkan bahwa lama kerja memiliki pengaruh terhadap kadar AST $(\mathrm{P}=0,035)$ namun tidak memiliki pengaruh terhadap kadar ALT $(\mathrm{P}=0,980)$. Peningkatan kadar AST dapat disebabkan karena terjadinya akumulasi pestisida akibat terlalu sering terjadi kontak dengan pestisida selama berkerja yang menyebabkan terjadinya kerusakan sel hati sehingga enzim ini beredar di darah dan konsentrasinya meningkat. Pada hubungan lama kerja dengan kadar ALT sejalan dengan penelitian yang dilakukan oleh Desimal pada tahun 2013 menunjukkan bahwa masa kerja (jam kerja/hari) tidak memiliki pengaruh terhadap kadar ALT pada petani apel di Kota Batu. Hal ini disebabkan karena beberapa hal diantaranya pada kondisi normal, sel hepatosit pada organ hati masih mampu mengalami biotransformarsi toksin. Namun apabila telah terjadi kerusakan hati, maka telah terjadi kerusakan sel hepatosit sehingga enzim aminotransferase beredar dalam darah dan ditemukan dalam kadar yang tinggi. Kebiasaan mengkonsumsi makanan dan minuman sehat seperti jahe dan vitamin $\mathrm{C}$ juga mampu memperbaiki kerusakan hati sehingga mampu menurunkan kadar enzim aminotransferase dalam darah. Selain itu, pemakaian APD yang tertib pada petani juga dapat mencegah terjadinya kontak langsung dengan pestisida sehingga dapat mencegah kerusakan hati akibat paparan pestisida. 
Pengaruh Pemakaian Alat Pelindung Diri (APD) terhadap Kadar AST dan ALT

Berdasarkan hasil analisis
statistik menggunakan One Way
ANOVA menunjukkan bahwa pemakaian APD memiliki pengaruh yang signifikan terhadap kadar AST $(\mathrm{P}=0,044)$ dan tidak memiliki pengaruh terhadap kadar ALT $(\mathrm{P}=0,853)$. Hasil penelitian ini sejalan dengan hasil penelitian yang dilakukan oleh Tsani pada tahun 2017 yang menyebutkan bahwa tidak ada pengaruh pemakaian APD terhadap kadar ALT pada petani di Kabupaten Magelang. Pemakaian APD seperti masker, sarung tangan, pakaian kedap air dan penutup kepala mampu meminimalisir terjadinya kontak dengan pestisida, dimana pestisida dapat masuk kedalam kulit melalui mulut, hidung dan kulit, sehingga dengan memakai APD, jalur masuk pestisida kedalam tubuh dapat dilindungi secara efisien. Sedangkan peningkatan kadar AST dapat disebabkan karena pemakaian APD yang digunakan oleh petani hanya menggunakan masker, jadi tidak menutup kemungkinan pestisida masuk melalui kulit sehingga menyebabkan terjadinya akumulasi pestisida dalam tubuh. ALT merupakan enzim utama yang paling banyak terdapat didalam sel hepatosit dan ditemukan dalam jumlah sedikit di oto, jantung, dan ginjal. Sedangkan AST merupakan enzim yang paling banyak terdapat di otot, jantung dan ginjal dan terdapat sedikit di dalam sel hepatosit. Peningkatan kadar AST menunjukkan telah terjadi kerusakan hati dan dan dapat menyebabkan infark miokard (serangan jantung) (Manfo 2020).

\section{KESIMPULAN}

Berdasarkan hasil penelitian, dapat diambil beberapa kesimpulan berikut:

Paparan pestisida dalam jangka waktu yang lama dapat menimbulkan kerusakan hati yang ditandai dengan meningkatnya kadar enzim AST dan ALT. Untuk mencegah hal tersebut, maka petani wajib mematuhi aturan terkait penggunaan pestisida seperti tertib memakai APD dan menjaga tubuh tetap sehat melalui asupan makanan yang sehat. 


\section{DAFTAR PUSTAKA}

Desimal, Iwan. Mukono, Jojok. 2013. The Effects Of Organophosphate Pesticides Exposure To Liver Function And Cholinesterase Serum Activity Among Apple Growers Applying Pesticides. The Indonesian Journal of Public Health, Vol. 10 No. 1,p 70-76

Direktorat Jendral Prasarana dan Sarana Direktorat Pupuk dan Pestisida Kementerian Pertanian 2011. Pedoman Pembinaan Penggunaan Pestisida

EFLM (European Federation of Clinical Chemistry and Laboratory Medicine) Recommendation for Venous Blood Sampling, 2017

Manfo, FPT., Mboe, S.A, Nantia, E.A, Ngoula, Ferdinand., Telefo, P.B., Moundipa P.F, and Fidelis Cho-Ngwa. 2020. Evaluation of the Effects of Agro Pesticides Use on Liver and Kidney Function in Farmers from Buea, Cameroon. Hindawi Journal of Toxicology Volume 2020, Article ID 2305764, 10 pages

Misrha, Sankalp. 2012. Serum and Hepatocyte Enzyme. Journal Of Scientific \& Innovative Research, Volume 1 Issue 3

Peraturan Menteri Pertanian Republik Indonesia Nomor 39/Permentan/Sr.330/7/2015 Tentang Pendaftaran Pestisida
Rehman,

Tanzila., Hussain, Mazhar., Shad, M.A, Ghosh, Sirsendu., and Muhammad Aslam. 2017. Combined Effect of Age and Exposure on the Levels of Different Serum Enzymes in Workers of Pesticides Formulation Factories, Pakistan. Biochem Physiol, Vol 7(2): 238

Rizvi, Farwa., Beg, Atif., Afzal, Muhammad and Abdul Majid Rajput. 2013. Association of Transaminase Levels with Obesity, Serum Lipids, Diabetes, Smoking and Level of Physical Activity. Journal of Islamabad Medical \& Dental College (JIMDC):2(1):21-25

Standard Operating Procedure for Collecting, Proccessing, and Storage of Blood Samples, 2017

Tsani, R.A., Setiani, Onny., Dewanti, N.A.Y. 2017. Hubungan Riwayat Pajanan Pestisida Dengan Gangguan Fungsi Hati Pada Petani Di Desa Sumberejo Kecamatan Ngablak Kabupaten Magelang. JURNAL KESEHATAN

MASYARAKAT (e-Journal) Volume 5, Nomor 3, Juli

Lomanorek, V.Y., Youla A. Assa, Yanti M. Mewo. 2016. Gambaran Kadar Serum Serum Glutamic Oxaloacetic Transaminase (Sgot) Pada Perokok Aktif Usia $>40$ Tahun. Jurnal e-Biomedik (eBm), Volume 4, Nomor 1, Januari-Juni 2016 
Widarti, Nurqaidah. 2019. Analisis Kadar Serum Glutamic Pyruvic Transaminase (SGPT) Dan Serum Glutamic Oxaloacetic Transaminase (SGOT) Pada Petani Yang Menggunakan Pestisida. Jurnal Media Analis Kesehatan, Vol. 10, No.1
Yuantari, M. G. C., Widianarko B., Sunoko, H. R. 2015. Analisis Risiko Pajanan Pestisida Terhadap Kesehatan Petani. KEMAS 10 (2) (2015) 239-245

Wulandari, DD., Santoso, APR. 2020. Pengaruh Lama Paparan Pestisida Terhadap Aktivitas Kolinesterase, Serum Glutamic Oxaloacetic Transaminase (SGOT) Dan Serum Glutamic Pyruvic Transaminase (SGPT) Pada Pekerja Yang Terpapar Pestisida Golongan Organofosfat. Sains dan Terapan Kimia, Vol. 14, No. 1 (Januari 2020), 9-16 